\title{
Penerapan Metode Inkuiri Terbimbing Terhadap Keterampilan Proses Sains dan Hasil Belajar Siswa SMP
}

\author{
Mansur $\mathbf{S}^{\mathbf{1}^{*}}$ \\ ${ }^{1}$ Program Studi S-1 Pendidikan Biologi, Fakultas Keguruan dan Ilmu Pendidikan, Universitas Nusa \\ Nipa, Indonesia
}

Email:mansursaputra00@gmail.com

\begin{tabular}{|c|c|}
\hline Info Artikel & Abstrak \\
\hline $\begin{array}{l}\text { Diterima: } 19 \text { September } 2021 \\
\text { Direvisi: } 22 \text { Oktober } 2021 \\
\text { Diterima } \\
\text { untuk diterbitkan: } 3 \text { November } \\
2021\end{array}$ & $\begin{array}{l}\text { Penelitian ini bertujuan untuk mengetahui efektivitas metode } \\
\text { inkuiri terbimbing ditinjau dari keterampilan proses sains dan } \\
\text { hasil belajar kognitif siswa kelas VII di SMP. Metode yang } \\
\text { digunakan adalah metode inkuiri terbimbing dengan desain } \\
\text { penelitian eksperimen semu. Populasinya adalah seluruh siswa }\end{array}$ \\
\hline $\begin{array}{l}\text { Keywords: } \\
\text { Inkuiri Terbimbing, } \\
\text { Keterampilan Proses Sains, } \\
\text { Hasil Belajar }\end{array}$ & $\begin{array}{l}\text { kelas VII SMP Negeri } 3 \text { Maumere. Sampelnya adalah siswa } \\
\text { kelas VII-A terdiri dari } 26 \text { siswa untuk kelas eksperimen, dan } \\
\text { siswa kelas VII-B terdiri dari } 25 \text { siswa untuk kelas kontrol. } \\
\text { Variabel yang digunakan adalah tes hasil belajar yang berupa } \\
\text { tes uraian yang telah diuji validitas dan reliabilitasnya. Analisis } \\
\text { data kedua kelompok menggunakan uji-t pada keterampilan } \\
\text { proses sains, diperoleh hasil yaitu } 0,003<0,05 \text { dan uji-t pada } \\
\text { hasil belajar kognitif diperoleh hasil yaitu } 0,009<0,05 \text {. Hal ini } \\
\text { menunjukkan bahwa terdapat pengaruh signifikan dengan } \\
\text { metode inkuiri terbimbing terhadap keterampilan proses sains } \\
\text { dan hasil belajar kognitif siswa kelas VII di SMP Negeri } 3 \\
\text { Maumere. }\end{array}$ \\
\hline
\end{tabular}

(C) 2021 Universitas Bengkulu. This is an open-access article under the CC-BY license (https://creativecommons.org/licenses/by/4.0)

\section{PENDAHULUAN}

Pembelajaran yang bertujuan untuk meningkatkan kemampuan siswa secara optimal harus dilakukan melalui langkah terstruktur dan terukur (Setiawan \& Koimah, 2019). Struktur pembelajaran yang baik diterapkan mulai dari langkah sederhana sampai rumit. Langkah-langkah ini dilakukan supaya dapat diukur baik dari sisi pelaksanaan maupun pencapaian. Hal ini berlaku secara umum terutama pada pembelajaran Ilmu Pengetahuan Alam (IPA).

Pembelajaran IPA yang baik adalah pembelajaran yang dapat memberikan kontribusi terhadap siswa baik dalam memahami pembelajaran maupun dalam membentuk keterampilan proses sains dan hasil belajar kognitifnya. Pemahaman konsep akan berdampak pada hasil belajar yang diperoleh. Hasil belajar diperoleh dari penilaian yang dilakukan oleh guru. Kunandar (2013) menyatakan penilaian hasil belajar merupakan kegiatan menilai peserta didik yang menekankan pada apa yang seharusnya dinilai, baik proses maupun hasil yang disesuaikan dengan tuntutan kompetensi. Penilaian berfungsi untuk mengetahui seberapa besar keberhasilan siswa dalam 
menguasai kompetensi atau materi yang telah diajarkan oleh pendidik.

Pembelajaran IPA di Sekolah Menengah Pertama (SMP) menekankan pada pemberian pengalaman belajar secara langsung melalui penggunaan dan pengembangan keterampilan proses dan sikap ilmiah (Kemendikbud, 2013). Keterampilan proses sains (KPS) adalah keterampilan berpikir yang digunakan para ilmuwan untuk membangun pengetahuan dalam rangka untuk memecahkan suatu masalah dan merumuskan hasil (Ozgelen, 2012). Pengembangan modul IPA berbasis KPS ini dinilai efektif karena selain hasil belajar siswa yang meningkat, keterampilan proses sains dari siswa itu sendiri mengalami peningkatan (Rosa, 2000).

Rustaman (2005) keterlibatan siswa secara aktif dalam proses pembelajaran dapat meningkatkan keterampilan proses sains dan hasil belajar siswa. Keterampilan yang terdapat dalam keterampilan proses sains, di antaranya mengamati (observasi), mengelompokkan (mengklasifikasi), menafsirkan (interpretasi), memprediksi, berhipotesis, dan mengkomunikasikan.

Pembelajaran IPA yang dilakukan di SMP Negeri 3 Maumere sudah menerapkan beberapa jenis metode atau model, namun belum sepenuhnya bisa menumbuhkan keterampilan proses sains (KPS) dan hasil belajar siswa. Berdasarkan informasi tersebut, pembelajaran di SMP Negeri 3 Maumere perlu diterapkan metode yang bisa menumbuhkan KPS dan hasil belajar siswa. Metode yang diprediksi dapat menumbuhkan KPS siswa yaitu metode pembelajaran inkuiri terbimbing. Inkuiri terbimbing adalah memperlihatkan kegiatan belajar yang membuat siswa aktif seperti mengamati, mengajukan pertanyaan, mengumpulkan informasi, dan mengklasifikasi.

Penerapan metode pembelajaran inkuiri terbimbing dapat meningkatkan hasil belajar siswa (Lailatur, 2009). Penerapan pembelajaran inkuiri terbimbing memberikan pengaruh yang signifikan terhadap keterampilan proses sains dasar siswa kelas VIII SMP Negeri 7 Surakarta (Ambarsari, 2013). Pembelajaran menggunakan metode pembelajaran inkuiri terbimbing dapat meningkatkan keterampilan proses sains dan aktivitas belajar siswa pada materi sistem reproduksi (Jumarni, 2014).

Metode pembelajaran inkuiri terbimbing merupakan metode yang tepat digunakan untuk menuntun keaktifan dalam pembelajaran. Keaktifan siswa dalam belajar tidak lain adalah untuk mengkonstruksi pengetahuan mereka sendiri, mereka aktif membangun pemahaman atas persoalan atau segala sesuatu yang mereka hadapi dalam kegiatan pembelajaran (Hermawan, 2007). Metode pembelajaran inkuiri menuntut siswa untuk aktif mencari informasi atau data mengenai materi pembelajaran yang diberikan. Informasi atau data dapat diperoleh melalui observasi lingkungan, eksperimen, pengumpulan data atau kajian pustaka, maupun metode lain sesuai dengan rancangan kegiatan yang dibuat oleh siswa.

\section{METODE}

\section{Desain Kegiatan}

Metode yang digunakan dalam kegiatan ini adalah Quasi Experiment. Pada kegiatan ini, terdapat dua kelas yang akan digunakan, yaitu kelas kontrol dan kelas eksperimen. Kelas kontrol merupakan kelas yang tidak sepenuhnya diberikan perlakuan, sedangkan kelas eksperimen merupakan kelas yang sepenuhnya diberikan perlakuan.

\section{Tabel 1}

Desain Kegiatan

\begin{tabular}{ccccc}
\hline No & Kelompok & Pretest & Perlakuan & Post test \\
\hline 1 & Eksperimen & $\mathrm{O}_{1}$ & $\mathrm{X}_{1}$ & $\mathrm{O}_{2}$ \\
2 & Kontrol & $\mathrm{O}_{1}$ & $\mathrm{X}_{2}$ & $\mathrm{O}_{2}$ \\
\hline
\end{tabular}

Ket:

E : Kelompok Eksperimen

K : Kelompok Kontrol

$\mathrm{X}_{1} \quad$ : Perlakuan Metode pembelajaran Inkuiri Terbimbing

$\mathrm{X}_{2} \quad$ : Perlakuan Metode Konvensional

$\mathrm{O}_{1} \quad$ : Pretest Keterampilan Proses Sains dan Hasil Belajar Kognitif Siswa

$\mathrm{O}_{2} \quad$ : Post test Keterampilan Proses Sains dan Hasil Belajar Kognitif Siswa 


\section{Teknik Pengumpulan Data}

Tes

Tes dilakukan untuk mengukur hasil belajar kognitif siswa dengan cara tes pada awal pembelajaran (pretest) dan akhir pembelajaran (post test). Tes ini diberikan kepada siswa untuk mengukur peningkatan hasil belajar kognitif siswa. Tes dilakukan sebelum pelajaran (pretest) dan pada akhir pembelajaran (post test).

Angket

Jenis angket dalam kegiatan ini adalah angket tertutup, yaitu disusun dengan menyediakan pilihan jawaban, sehingga siswa hanya memberi tanda pada jawaban yang dipilih. Masing-masing jawaban memiliki skor yang telah ditentukan untuk melihat peningkatan dari KPS siswa. Pemberian skor berdasarkan Skala Likert.

Observasi

Observasi digunakan untuk mengamati dan mendapatkan data tentang segala aktivitas guru dan aktivitas siswa selama proses pembelajaran berlangsung. Observasi juga digunakan untuk mengetahui kemampuan siswa dalam mengembangkan proses belajarnya pada keterampilan proses sains (KPS).

\section{Teknik Analisis Data}

\section{Uji Hipotesis}

Uji hipotesis (uji t) hasil belajar, terlebih dahulu dicari gain skor. Gain Skor adalah peningkatan kemampuan yang diperoleh siswa setelah menerima pembelajaran.

Rumus mencari gain skor adalah:

\section{Nilai posttest - nilai pretest}

Skor maksimal - nilai pretest

Analisis Data Angket

Angket yang digunakan pada penelitian ini berbentuk skala likert, dimana skala ini siswa memberikan respon terhadap pertanyaan-pertanyaan yang diberikan dengan memilih:

STS : jika sangat tidak setuju

TS : jika tidak setuju

KS : jika kurang setuju

S : jika setuju

SS : jika sangat setuju

Data angket dianalisis secara deskriptif dengan menggunakan persentase (\%) melalui rumus:

$$
P=\frac{\mathrm{f}}{\mathrm{N}} \times 100 \%
$$

\section{Keterangan:}

$\mathrm{P} \quad=$ angka persentase

$\mathrm{F} \quad=$ frekuensi yang dicari persentasenya

$\mathrm{N} \quad=$ banyaknya sampel responden

\section{Analisis Data Observasi}

Analisis lembar observasi untuk mengetahui peningkatan mental aktivitas belajar siswa. Kemudian dianalisis menggunakan analisis persentase. Untuk analisis persentase menggunakan rumus sebagai berikut:

$$
\text { Persentase } \%=\frac{\mathrm{S}}{\mathrm{N}} \times 100 \%
$$

\section{Keterangan:}

$\mathrm{P} \quad=$ Persentase pelaksanaan setiap indikator

$\mathrm{S} \quad=$ Jumlah skor perolehan untuk setiap indikator

$\mathrm{N} \quad=$ Jumlah skor total 


\section{HASIL DAN PEMBAHASAN}

Hasil keterampilan proses sains diperoleh melalui nilai pretest dan post test. Nilai pretest diperoleh dari hasil tes yang diberikan di awal pembelajaran ketika kedua sampel belum diberi perlakuan.

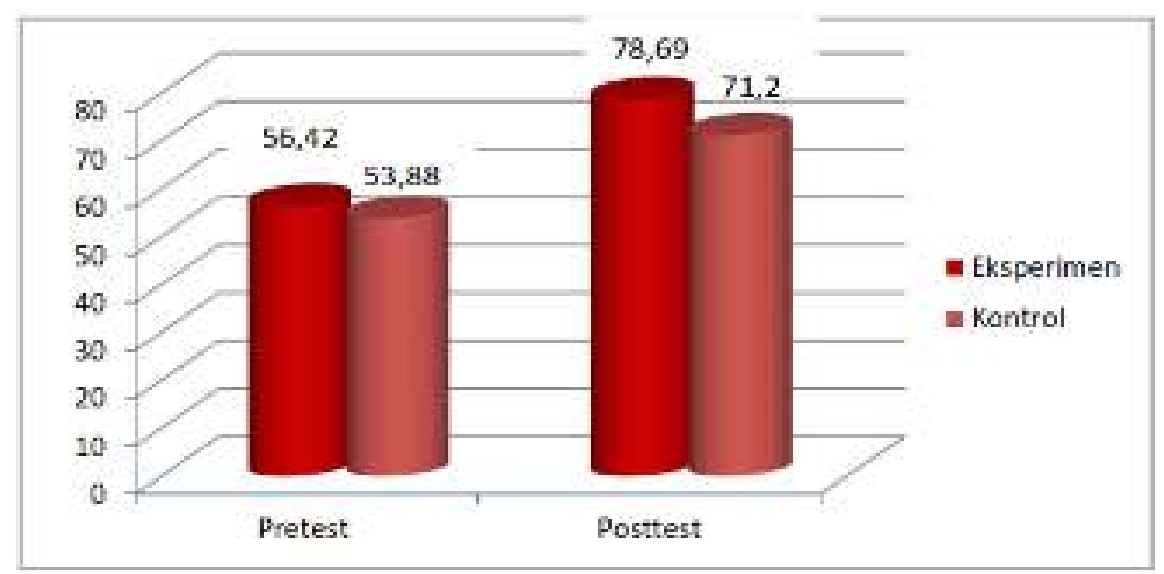

Gambar 1. Nilai Rata-rata Keterampilan Proses Sains Siswa

Hasil analisis data keterampilan proses sains (KPS) siswa kelas eksperimen lebih tinggi hasilnya dibandingkan kelas kontrol. Hal ini menunjukkan bahwa hasil keterampilan proses sains (KPS) siswa yang diberi pembelajaran dengan metode inkuiri terbimbing lebih tinggi hasilnya dibandingkan hasil keterampilan proses sains (KPS) siswa yang diberi pembelajaran dengan metode konvensional. Hasil analisis data keterampilan proses sains diambil dari dua kelas yaitu kelas VII-B sebagai kelas eksperimen dan VII-A sebagai kelas kontrol. Dari analisis dapat diketahui bahwa data hasil kegiatan tentang keterampilan proses sains berdistribusi normal dengan nilai pretest kelas eksperimen sebesar $0,170>0,05$, kelas kontrol sebesar $0,128>0,05$, nilai post test kelas eksperimen sebesar 0,139>0,05 dan kelas kontrol sebesar 0,138 >0,05. Hasil uji homogenitas diketahui varian bersifat homogen dengan nilai pretest sebesar $0,816>0,05$ dan post test sebesar $0,548>0,05$.

Hasil pembelajaran pada kelas eksperimen dan pembelajaran pada kelas kontrol, dilakukan uji-t terhadap nilai pretest dan post test untuk mengetahui pengaruh metode inkuiri terbimbing kelas eksperimen. Hasil uji tersebut memberikan nilai-t sebesar $0,003<0,05$, maka dapat disimpulkan bahwa metode inkuiri terbimbing berpengaruh terhadap keterampilan proses sains siswa. Kelas eksperimen memiliki keterampilan proses sains yang lebih tinggi dari kelas kontrol.

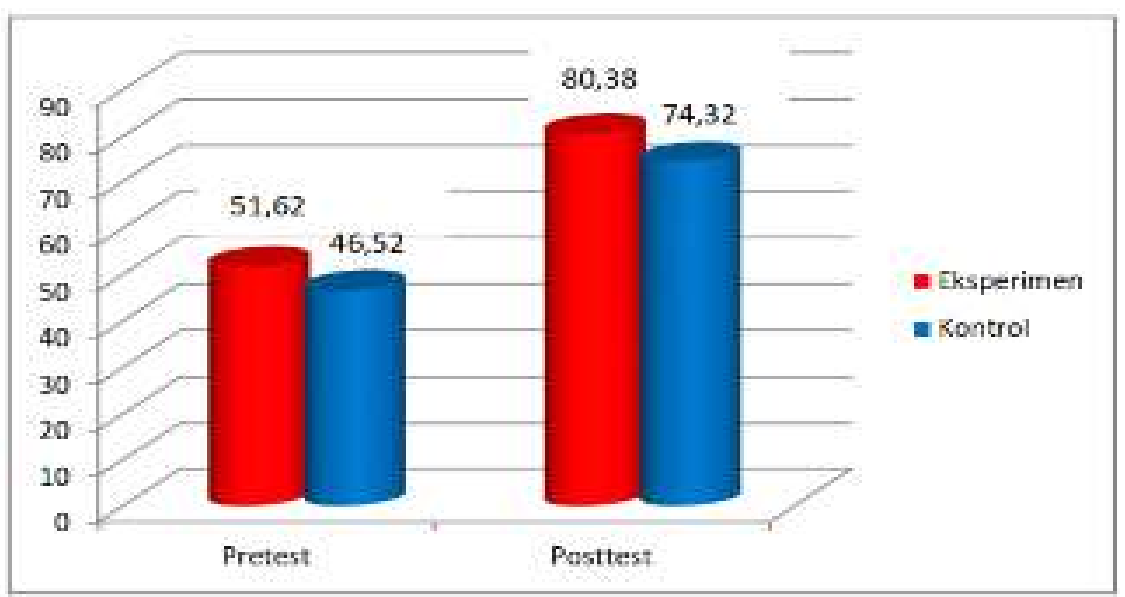

Gambar 2. Hasil pretest dan post test aspek kognitif siswa

Hasil analisis data hasil belajar kognitif siswa diambil dari dua kelas yaitu kelas VII-B sebagai kelas eksperimen dan VII-A sebagai kelas kontrol. Dari analisis dapat diketahui bahwa data 
kegiatan tentang hasil belajar kognitif siswa berdistribusi normal dengan nilai pretest kelas eksperimen sebesar $0,220>0,05$, kelas kontrol sebesar $0,451>0,05$, nilai post test kelas eksperimen sebesar 0,120 >0,05 dan kelas kontrol sebesar 0,178 >0,05. Hasil uji homogenitas diketahui varian bersifat homogen dengan nilai pretest sebesar $0,461>0,05$, dan post test sebesar $0,185>0,05$.

Pembelajaran dengan menggunakan metode inkuiri terbimbing pada kelas eksperimen dan pembelajaran konvensional pada kelas kontrol, selanjutnya dilakukan uji-t terhadap nilai pretest dan post test untuk mengetahui pengaruh metode inkuiri terbimbing kelas eksperimen. Hasil uji tersebut memberikan nilai-t sebesar 0,009 $<0,05$, maka dapat disimpulkan bahwa metode inkuiri terbimbing berpengaruh terhadap hasil belajar kognitif siswa. Kelas eksperimen memiliki hasil belajar kognitif yang lebih tinggi dari kelas kontrol.

\section{Efektivitas Metode Inkuiri Terbimbing Ditinjau Dari Keterampilan Proses Sains Siswa}

Keterampilan proses sains merupakan kemampuan berpikir yang digunakan untuk membangun pengetahuan dalam rangka untuk memecahkan suatu masalah dan merumuskan hasil. Keterampilan proses sains pada kegiatan ini meliputi mengamati (observasi), mengelompokkan (mengklasifikasi), menafsirkan (interpretasi), memprediksi, berhipotesis, dan mengkomunikasikan (Rustaman, 2005). Data keterampilan proses sains siswa diperoleh dari nilai pretest, nilai post test, dan angket keterampilan proses sains siswa.

Pada metode pembelajaran inkuiri terbimbing, siswa didorong untuk belajar secara mandiri. Siswa belajar melalui keterlibatan aktif dengan konsep-konsep yang diberikan dan pendidik mendorong siswa untuk mendapatkan pengalaman dengan melakukan kegiatan yang memungkinkan mereka menemukan konsep. Inkuiri terbimbing dapat terjadi apabila siswa terlibat aktif dalam menggunakan proses mental agar memperoleh pengalaman, sehingga memungkinkan untuk menemukan konsep. Proses mental tersebut di atas melibatkan keterampilan proses sains yang lebih tinggi tingkatannya (orientasi, merumuskan masalah, mengajukan hipotesis, mengumpulkan data, menganalisis data, merumuskan kesimpulan).

Keterampilan proses sains sangat penting dalam kegiatan pembelajaran. Keterampilan proses sains tidak hanya mencari keterampilan yang bisa membuat siswa belajar banyak informasi mengenai sains, tetapi juga mempelajari keterampilan yang membantu siswa untuk berpikir logis, mengajukan pertanyaan rasional dan mencari jawabannya, serta memecahkan masalah mereka dalam kehidupan sehari- hari (Ergul dkk, 2011). Siswa yang memiliki nilai keterampilan proses sains yang tinggi berarti siswa tersebut lebih aktif dalam pembelajaran dibandingkan dengan siswa yang mempunyai nilai keterampilan proses sains yang rendah. Oleh karena itu, penggunaan metode pembelajaran inkuiri terbimbing harus efektif terhadap keterampilan proses sains siswa, sehingga keterampilan siswa dapat meningkat.

\section{Efektivitas Metode Inkuiri Terbimbing Ditinjau Dari Hasil Belajar Siswa}

Berdasarkan analisis deskriptif hasil belajar kognitif siswa menunjukkan hasil bahwa siswa yang diajarkan dengan metode pembelajaran inkuiri terbimbing memiliki hasil yang lebih baik dibandingkan dengan siswa yang diajarkan dengan metode pembelajaran konvensional (ceramah, diskusi, dan tanya jawab). Susanto (2013) penggunaan metode pembelajaran yang tepat akan turut menentukan efektivitas, efisiensi pembelajaran, serta hasil belajar. Hal ini dapat diketahui dari nilai siswa kelas eksperimen lebih besar dibandingkan dengan kelas kontrol. Hasil kegiatan ini dapat disimpulkan terdapat efek metode pembelajaran inkuiri terbimbing terhadap hasil belajar kognitif siswa.

Sribekti dkk (2000) kegiatan inti pada kelas eksperimen berupa mengidentifikasi masalah, mengamati lingkungan sekolah, membedakan ciri makhluk hidup dan tak hidup, mencatat apa yang diamati, dan mempresentasikan hasil pengamatan. Pada kelas eksperimen siswa dituntut untuk aktif dalam kegiatan pembelajaran. Siswa yang aktif nantinya akan dilihat pada hasil belajarnya. Hasil belajar siswa yang menggunakan metode pembelajaran inkuiri terbimbing berbeda dengan hasil belajar siswa yang menggunakan metode konvensional (ceramah, diskusi, dan tanya jawab). Dewi dkk (2013) terdapat perbedaan hasil belajar secara signifikan antara siswa yang belajar dengan menggunakan metode inkuiri terbimbing dengan metode pembelajaran konvensional. 
Kegiatan pembelajaran pada kelas eksperimen dengan menggunakan metode pembelajaran inkuiri terbimbing dilakukan di sekitar lingkungan sekolah. Tujuan memanfaatkan lingkungan sekitar agar pembelajaran yang berlangsung tidak membosankan dan siswa lebih paham bendabenda yang ada di sekitar lingkungan sekolah. Karena dengan membawa siswa langsung ke tempatnya, siswa akan lebih memahami apa-apa saja yang ada di lingkungan sekolah tersebut dan manfaat lingkungan sekolahnya. Siswa tidak hanya belajar dengan teori tetapi langsung melihat benda sekitar. Widiasworo (2017) menyatakan bahwa kegiatan mempelajari lingkungan dalam proses belajar mengajar akan lebih bermakna sebab siswa dihadapkan langsung pada situasi dan keadaan yang sebenarnya. Sementara, siswa yang belajar pada kelas kontrol dengan menggunakan metode konvensional (ceramah, diskusi, dan tanya jawab) atau pembelajaran yang masih berpusat pada guru membuat siswa malas mencari tahu. Sati dkk (2020) peningkatan nilai hasil belajar siswa pada setiap siklus menunjukkan bahwa pembelajaran model inkuiri dapat meningkatkan hasil belajar siswa kelas VII I SMP San Carlos Habi. Mansur \& Loli (2019) hasil penelitian menunjukkan dapat meningkatkan hasil belajar siswa kelas VIII pada pokok bahasan sistem peredaran darah pada manusia dengan ketuntasan siswa sebesar 85,7\% dan keaktifan siswa dalam proses belajar meningkat sebesar $81,81 \%$.

Siswa di kelas kontrol memberikan respon yang lebih rendah jika diberikan pertanyaan maupun jika diminta mengerjakan latihan, serta mereka kurang aktif bertanya dibandingkan pada kelas eksperimen. Hal ini dibuktikan ketika guru mengajukan pertanyaan hanya beberapa siswa yang mempunyai inisiatif untuk menjawab pertanyaan guru. Rendahnya keingintahuan siswa dapat berdampak pada hasil belajarnya. Rasa ingin tahu merupakan modal awal bagi siswa dalam proses pembelajaran (Ameliah dkk, 2016). Sedangkan Mansur dkk (2021) dapat meningkatkan motivasi dan hasil belajar siswa pada materi pokok Invertebrata kelas X SMAS Katolik Caritas Maumere. Dengan keingintahuan yang tinggi maka siswa akan belajar lebih, guna memenuhi kehausan akan pengetahuan yang ingin diketahui.

\section{KESIMPULAN}

Metode pembelajaran inkuiri terbimbing efektif terhadap keterampilan proses sains siswa kelas VII SMP Negeri 3 Maumere. Hasil kegiatan nilai rata-rata pretest pada kelas eksperimen sebesar 56,42 kelas kontrol sebesar 53,88. Nilai post test keterampilan proses sains (KPS) siswa kelas eksperimen sebesar 78,69 dan kelas kontrol sebesar 71,2. Metode pembelajaran inkuiri terbimbing efektif terhadap hasil belajar kognitif siswa kelas VII SMP Negeri 3 Maumere. Hasil kegiatan rata-rata nilai pretest hasil belajar kognitif siswa kelas eksperimen sebesar 51,62 dan kelas kontrol sebesar 46,52. Post test hasil belajar kognitif siswa kelas eksperimen sebesar 80,38 dan kelas kontrol sebesar 74,32.

\section{DAFTAR PUSTAKA}

Ambarsari, W. (2013). Penerapan Pembelajaran Inkuiri Terbimbing Terhadap Keterampilan Proses Sains Dasar Pada Pelajaran Biologi Siswa Kelas VIII SMP Negeri 7 Surakarta. Jurnal Pendidikan Biologi, 5(1), 81-95.

Ameliah, I. H., Munawaroh, M., \& Muchyidin, A. (2016). Pengaruh Keingintahuan dan Rasa Percaya Diri Siswa Terhadap Hasil Belajar Matematika Kelas VII MTs Negeri I Kota Cirebon. EduMa, 5(1), 9-21.

Dewi., Lestari, N., Dantes, N., \& Sadia, I. W. (2013). Pengaruh Model Pembelajaran Inkuiri Terbimbing Terhadap Sikap Ilmiah dan Hasil Belajar IPA. E-Jurnal Pascasarjana Undiksha, 3(1), 31-47.

Ergul, R., \& Simsekli, S. (2011). The Effects of Inquiry-Based Science Teaching on Elementary School Students Science Process Skills and Science Attitudes. Bulgarian Jurnal of Science and Education Policy (BJSEP), 5(1), 48-68. 
Hermawan. (2007). Belajar dan Pembelajaran. Jakarta: PT Asdi Mahasatya.

Jumarni, N., Jalmo, T., \& Yolida, B. (2014). Pengaruh Penerapan Model Pembelajaran Inkuiri Terbimbing Terhadap Keterampilan Proses Sains. Jurnal Boiterdidik, 2(1), 1-3.

Kemendikbud. (2013). .Implementasi Kurikulum 2013 SMP/MTs Ilmu Pengetahuan Alam. Jakarta: Badan Pengembangan Sumber Daya Manusia Pendidikan dan Kebudayaan dan Penjaminan Mutu.

Kunandar. (2013). Penilaian Autentik (Penilaian Hasil Belajar Peserta Didik Berdasarkan Kurikulum 2013). Jakarta: Rajawali Press.

Lailatur, R. (2009). Pengaruh Penerapan Model Pembelajaran Inkuiri Terbimbing Terhadap Prestasi Belajar Kimia Materi Hidrokarbon dan Respon Siswa Kelas X MAN 3 Malang Tahun Ajaran 2009/2010. Universitas Malang, Indonesia.

Mansur, S., \& Loli, M. P. P. (2019). Upaya Meningkatkan Hasil Belajar Siswa Kelas VII Dengan Model Guided Note Taking di SMP San Carlos Habi. Biosfer: Jurnal Tadris Biologi, 10(1), 21-28. doi: https://doi.org/10.24042/biosfer.v10i1.3990.

Mansur, S., Raida, S. A., \& Putra, S. H. J. (2021). Pembelajaran Picture and Picture untuk Meningkatkan Motivasi dan Hasil Belajar Siswa Pada Materi Invertebrata. Journal of Biology Education, 4(1), 72-79. doi: http://dx.doi.org/10.21043/jobe.v4i1.9796.

Ozgelen, S. (2012). Students' Science Process Skills within a Cognitive Domain Framework. Eurasia Journal of Mathematics, Science, \& Technology Education, 8(4). doi: https://doi.org/10.12973/eurasia.2012.846a.

Rosa, F. O. (2015) Pengembangan Modul Pembelajaran IPA SMP Pada materi Tekanan Berbasis Keterampilan Proses Sains. Jurnal Pendidikan Fisika, Universitas Muhammadiyah Metro.

Rustaman, N. Y. (2005). Strategi Belajar Mengajar Biologi. Malang: UPI Press.

Sati, S., S, M., \& Galis, R. (2020). Penerapan Model Pembelajaran Inkuiri Untuk Meningkatkan Hasil Belajar Biologi Siswa Pada Pokok Bahasan Ekosistem di SMP San Carlos Habi. Spizaetus: Jurnal Biologi dan Pendidikan Biologi, 1(1), 27-32.

Setiawan, Adib, R., \& Koimah, S. (2019). Effective Learning and Teaching. Thesis Commons. doi: https://dx.doi.org/10.31237/osf.io/p42nx.

Sribekti, Y., Ibrrohim., \& Hidayat. A. (2000). Peningkatan Keterampilan Proses Sains dan Hasil Belajar Kognitif Siswa Kelas VII SMP Negeri 1 Selorejo Menggunakan Perangkat Pembelajaran Ekosistem Berbasis Inkuiri Terbimbing Dengan Sumber Belajar Waduk Lahor. Jurnal Pendidikan, 1(8), 1575-1580. doi: http://dx.doi.org/10.17977/jp.v1i8.6671.

Susanto, A. (2013). Teori Belajar dan Pembelajaran di Sekolah Dasar. Jakarta: Kencana.

Widiasworo, E. (2017). Strategi dan Metode Mengajar Siswa di Luar Kelas. Yogyakarta: ARRUZZ MEDIA. Retrieved from http://hdl.handle.net/2123/7128. 